\title{
EFFECTS OF KAOLIN ADDITIONS ON THERMAL BEHAVIORS OF RIGID POLYURETHANE FOAMS
}

\author{
B. Aydoğan ${ }^{1}$, N. Usta ${ }^{2 *}$
}

\begin{abstract}
Thermal insulation is very important issue in many industrial applications and different materials are preferred to satisfy the thermal insulation depending on the applications. One of the most important properties of the thermal insulation materials is low thermal conductivity. In addition, the cost of the material is another important factor. Among the thermal insulation materials, rigid polyurethane foams are used in automotive, transportation and building sectors due to lower thermal conductivity. Although the thermal conductivity of the rigid polyurethane foam is lower than those of many other thermal insulation materials, other thermal insulation materials may be preferred in some applications due to their lower costs. Therefore, different natural inorganic minerals have been added as fillers into the foams, mainly to reduce raw materials costs. In this study, kaolin, which is a cheap natural inorganic mineral, was incorporated into rigid polyurethane foams in 5,10 and $15 \%$ in mass. Effects of kaolin addition on thermal decomposition and thermal conductivity of rigid polyurethane foams were investigated. The results revealed that the incorporations of kaolin into the foams slightly increased the thermal conductivities of the foams. However, it was found that kaolin addition enhanced the thermal stability of rigid polyurethane foams.
\end{abstract}

\section{Keywords: Rigid Polyurethane, Kaolin, Thermal Conductivity, Thermal Decomposition}

\section{INTRODUCTION}

Different kinds of materials are used to satisfy thermal insulation in many industrial applications. There are mainly two important factors for choosing the thermal insulation materials. First factor is low thermal conductivity and second one is the price of the material. Rigid polyurethane foam (PUR) is preferred in many industrial applications such as automotive, transportation and building sectors due to its low thermal conductivity [1-4]. Although, the thermal conductivity of PUR is lower than those of many thermal insulation materials, PUR is not preferred in some applications due to its higher price. Therefore, natural inorganic minerals like clay, talk and calcite have been used as fillers in rigid polyurethane foam productions to reduce raw materials costs [5-7]. The particle size, chemical composition and amount of filler are important parameters affecting the thermal conductivity, mechanical and thermal stability of the foams [8]. In addition, there is an important issue related to usage of the rigid polyurethane foams. The thermal conductivity coefficients of the foams increase by time and it is called as thermal aging [9]. Therefore, thermal aging of the foams filled with inorganic minerals should be investigated.

Moreover, pure rigid polyurethane foams have low thermal stability and low resistance to fire. When they are exposed to the external heat flux, they are easily decomposed and combustible/non-combustible gases and smoke may be released [10-13]. The addition of natural mineral matters may enhance the thermal stability of the foams [14-17]. In this study, effects of 5, 10 and $15 \mathrm{wt} . \%$ kaolin additions on thermal degradation behavior and thermal conductivity coefficient of the rigid polyurethane foams (PUR) were investigated.

\section{MATERIALS AND METHODS Materials}

Isocyanate (PMDI 92140) and polyol (Evopur-1122-28) which are the raw materials of the rigid polyurethane foam were bought from TEKPOL Ltd. (Turkey). The densities of polyol and isocyanate at $25^{\circ} \mathrm{C}$ are $1130 \mathrm{~kg} / \mathrm{m}^{3}$ and $1230 \mathrm{~kg} / \mathrm{m}^{3}$, respectively. Meanwhile, the viscosities of polyol and isocyanate at $25{ }^{\circ} \mathrm{C}$ are 300 mPa.s and 210 mPa.s, respectively. OMYA Mining Ltd. (Turkey) generously supplied the kaolin which is mainly composed of $77.96 \% \mathrm{SiO}_{2}, 19.39 \% \mathrm{Al}_{2} \mathrm{O}_{3}, 1.01 \% \mathrm{CaO}, 0.45 \% \mathrm{MgO}$. The average particle size $\left(\mathrm{d}_{50}\right)$ of the kaolin is about $4 \mu \mathrm{m}$.

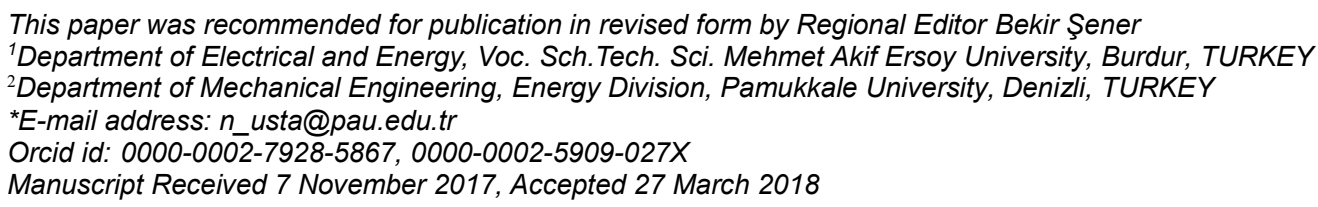




\section{Sample Production}

Initially, kaolin (KAO) which was dried at $100^{\circ} \mathrm{C}$ for 24 hours to remove the moisture was added into the polyol and homogenization of the kaolin-polyol mixture was performed by using a mechanical homogenizer (Heidolph Silent Crusher M Model) running at 20,000 rpm for $5 \mathrm{~min}$. Then the isocyanate was added into the kaolin-polyol mixture and they were stirred by using a mechanical stirrer (Heidolph Overhead Stirrer RZR 2020) running at 3,000 $\mathrm{min}^{-1}$ for $12 \mathrm{~s}$. The amounts of the polyol and the isocyanate were reduced as the amount of kaolin addition to keep the density of the foam at $40 \pm 0.5 \mathrm{~kg} / \mathrm{m}^{3}$. The mixture was poured into the aluminum mold which was pre-heated at $40{ }^{\circ} \mathrm{C}$. The aluminum mold was kept under the press at $40{ }^{\circ} \mathrm{C}$ for $25 \mathrm{~min}$. The sample was removed from the mold and waited in the production laboratory for 24 hours in order to satisfy completion of the curing process of the foam. The detailed information about the samples is given in Table 1 and the sample production stages are shown in Fig.1.

Table 1. PUR and PUR/KAO composites

\begin{tabular}{|c|c|c|c|c|}
\hline Sample name & $\begin{array}{c}\text { PMDI 92140 Polyol } \\
\mathbf{( \% )}\end{array}$ & $\begin{array}{c}\text { Evopur-1122-28 Isocyanate } \\
\mathbf{( \% )}\end{array}$ & $\begin{array}{c}\text { Kaolin } \\
\mathbf{( \% )}\end{array}$ & $\begin{array}{c}\text { Total } \\
(\mathbf{\%})\end{array}$ \\
\hline PUR & 45.9 & 54.1 & - & 100 \\
\hline PUR+05KAO & 43.6 & 51.4 & 5 & 100 \\
\hline PUR+10KAO & 41.3 & 48.7 & 10 & 100 \\
\hline PUR+15KAO & 39.0 & 46.0 & 15 & 100 \\
\hline
\end{tabular}

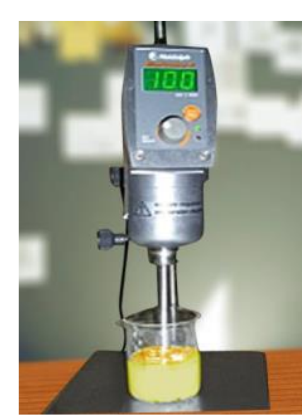

(a)

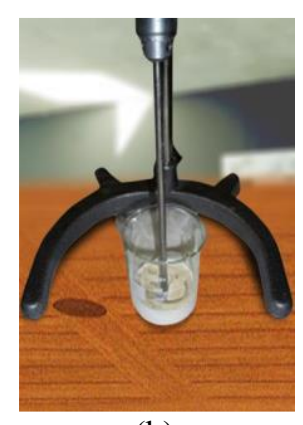

(b)

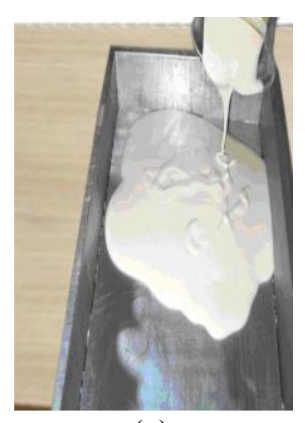

(c)

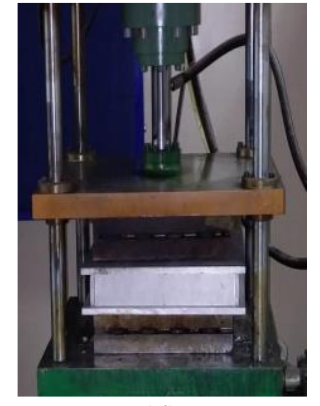

(d)

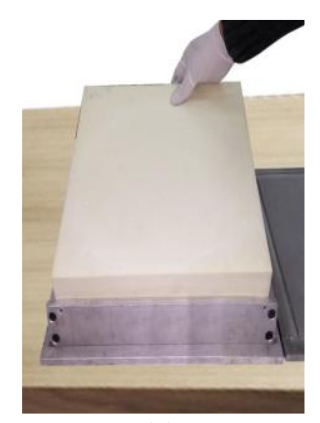

(e)

Figure 1. Sample production stages (a) Homogenization of polyol-kaolin (b) Mixing of isocyanate and polyolkaolin (c) Pouring of the mixture into the mold (d) Curing in a heated press (e) Removing the sample from the mold

\section{Thermogravimetric Analysis (TGA)}

Thermogravimetric analyzes are important tests to understand the structural and thermal properties of polymeric materials [18]. Perkin-Elmer Diamond TG/DTA was used to perform thermogravimetric analysis of the samples. Ceramic pans were used in the tests which were performed between 40 and $800{ }^{\circ} \mathrm{C}$ at a heating rate of 20 ${ }^{\circ} \mathrm{C} / \mathrm{min}$. High purity nitrogen gas was purged at a flowrate of $200 \mathrm{~mL} / \mathrm{min}$ to provide the inert environment in the oven of the equipment. The sample mass was adjusted as $10 \pm 1 \mathrm{mg}$ in the tests. The real time mass loss and derivative mass loss were recorded via PYRIS software of Perkin-Elmer Inc. during the experiment.

\section{Thermal Conductivity}

Kyoto QTM-500 which can measure the coefficient of thermal conductivity of thermal insulation materials within $5 \%$ accuracy was used to measure the thermal conductivity coefficients of the foams according to ASTM C1113 [19]. The thermal conductivity coefficient of each foam sample was determined as the average of three measurements.

\section{Average Cell Size Determination}

An optical Nikon SMZ 1500 Stereo microscope which was connected to a computer was used to examine the morphology of the foam samples. The images were analyzed and the cell sizes of the foams were measured according to ASTM D 3576-04 [20]. The cell size of each foam sample was determined as the average of five measurements. 


\section{RESULTS AND DISCUSSION}

Thermal decomposition behaviors of the samples were investigated with the thermogravimetric analysis. Figure 2 shows TG and DTG curves of PUR and PUR/KAO composites. In general, KAO additions did not significantly modify the decomposition mechanisms of PUR. There were three main decomposition mechanisms for both PUR and PUR/KAO composites. However, the main maximum decomposition temperature $\left(\mathrm{T}_{2 \max }\right)$ for the sample including $15 \mathrm{wt}$. \% KAO was obtained as $362.99^{\circ} \mathrm{C}$ which is $4.45^{\circ} \mathrm{C}$ higher than that of PUR $(358.54$ $\left.{ }^{\circ} \mathrm{C}\right)$. Meanwhile, the second maximum decomposition rate for PUR was obtained as $16.93 \% / \mathrm{min}$. This value was $12.96 \% / \mathrm{min}$ for PUR+15KAO. Addition of the kaolin into the foam resulted in increasing of the maximum decomposition temperatures and decreasing of the maximum decomposition rates [21, 22].The particles of kaolin acted like a barrier and prevented the volatiles to leave from the foam and decrease the decomposition rate of the material. $\mathrm{T}_{50 \mathrm{wt}}$ was increased approximately $38^{\circ} \mathrm{C}$ with the addition of $15 \mathrm{wt} . \% \mathrm{KAO}$. In addition, $\mathrm{KAO}$ addition increased the residues at $800{ }^{\circ} \mathrm{C}[9,23,24]$. Although the residue at $800{ }^{\circ} \mathrm{C}$ for PUR was $16.03,15$ wt. \% KAO addition increased the residue to $28.33 \%$. The detailed results are given in Table 2 .
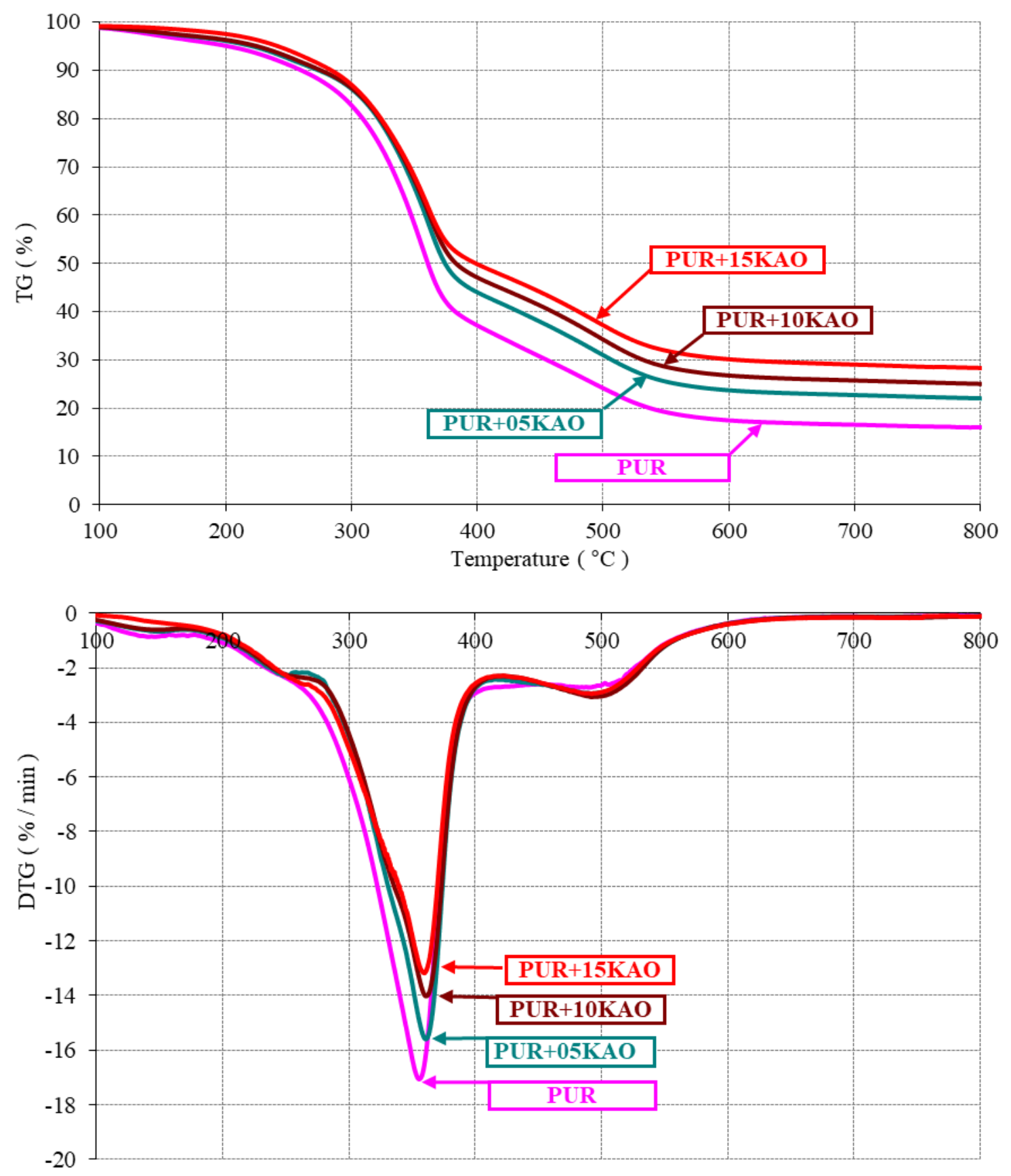

Figure 2. TG and DTG curves of PUR and PUR/KAO composites 
The effects of kaolin additions on the average cell size of the foams were found and shown in Figure 3. The average cell size of PUR was determined as approximately $690 \mu \mathrm{m}$. The average cell sizes increased with the addition of KAO. The cell sizes of PUR $+5 \mathrm{KAO}, \mathrm{PUR}+10 \mathrm{KAO}$ and PUR+15KAO were approximately 800,830 and $860 \mu \mathrm{m}$, respectively. Although the average particle size of $\mathrm{KAO}\left(\mathrm{d}_{50}\right)$ was about $4 \mu \mathrm{m}$, kaolin particles broke down some of the cell walls. Therefore, average cell sizes were increased depending on the kaolin content in the foam.

Table 2. The detailed results obtained by thermogravimetric analysis of the foams

\begin{tabular}{|c|c|c|c|c|}
\hline & \multicolumn{4}{|c|}{ SAMPLES } \\
\hline & PUR & PUR+05KAO & PUR+10KAO & PUR+15KAO \\
\hline $\mathrm{T}_{\% 5(\mathrm{~m} / \mathrm{m})}\left({ }^{0} \mathrm{C}\right)$ & 201.70 & 220.66 & 224.91 & 241.38 \\
\hline $\mathrm{T}_{\% 10(\mathrm{~m} / \mathrm{m})}\left({ }^{\circ} \mathrm{C}\right)$ & 260.13 & 273.69 & 275.75 & 283.99 \\
\hline $\mathrm{T}_{\% 50(\mathrm{~m} / \mathrm{m})}\left({ }^{\circ} \mathrm{C}\right)$ & 360.36 & 374.37 & 383.07 & 398.81 \\
\hline $\begin{array}{l}T_{1 \text { maks }}\left({ }^{\circ} \mathrm{C}\right) \\
R_{1 \text { maks }}(\% / \text { min })\end{array}$ & $\begin{array}{c}143.29 \\
-0.8218\end{array}$ & $\begin{array}{c}157.34 \\
-0,6287\end{array}$ & $\begin{array}{c}159.07 \\
-0,6081\end{array}$ & $\begin{array}{c}163.5 \\
-0.4042\end{array}$ \\
\hline $\begin{array}{l}T_{2 \text { maks }}\left({ }^{\circ} \mathrm{C}\right) \\
\mathbf{R}_{2 \text { maks }}(\% / \mathrm{min})\end{array}$ & $\begin{array}{l}358.54 \\
-16.93 \\
\end{array}$ & $\begin{array}{l}363.72 \\
-15.50 \\
\end{array}$ & $\begin{array}{l}364.39 \\
-13.91 \\
\end{array}$ & $\begin{array}{l}362.99 \\
-12.96 \\
\end{array}$ \\
\hline $\begin{array}{l}T_{3 \text { maks }}\left({ }^{\circ} \mathrm{C}\right) \\
\mathrm{R}_{3 \text { mak }}(\% / \mathrm{min}) \\
\end{array}$ & $\begin{array}{l}497.48 \\
-2.646 \\
\end{array}$ & $\begin{array}{l}506.35 \\
-2.827 \\
\end{array}$ & $\begin{array}{l}507.29 \\
-2.981 \\
\end{array}$ & $\begin{array}{l}506.37 \\
-2.803 \\
\end{array}$ \\
\hline Residue at $800{ }^{\circ} \mathrm{C}(\%)$ & 16.03 & 22.04 & 25.04 & 28.33 \\
\hline
\end{tabular}

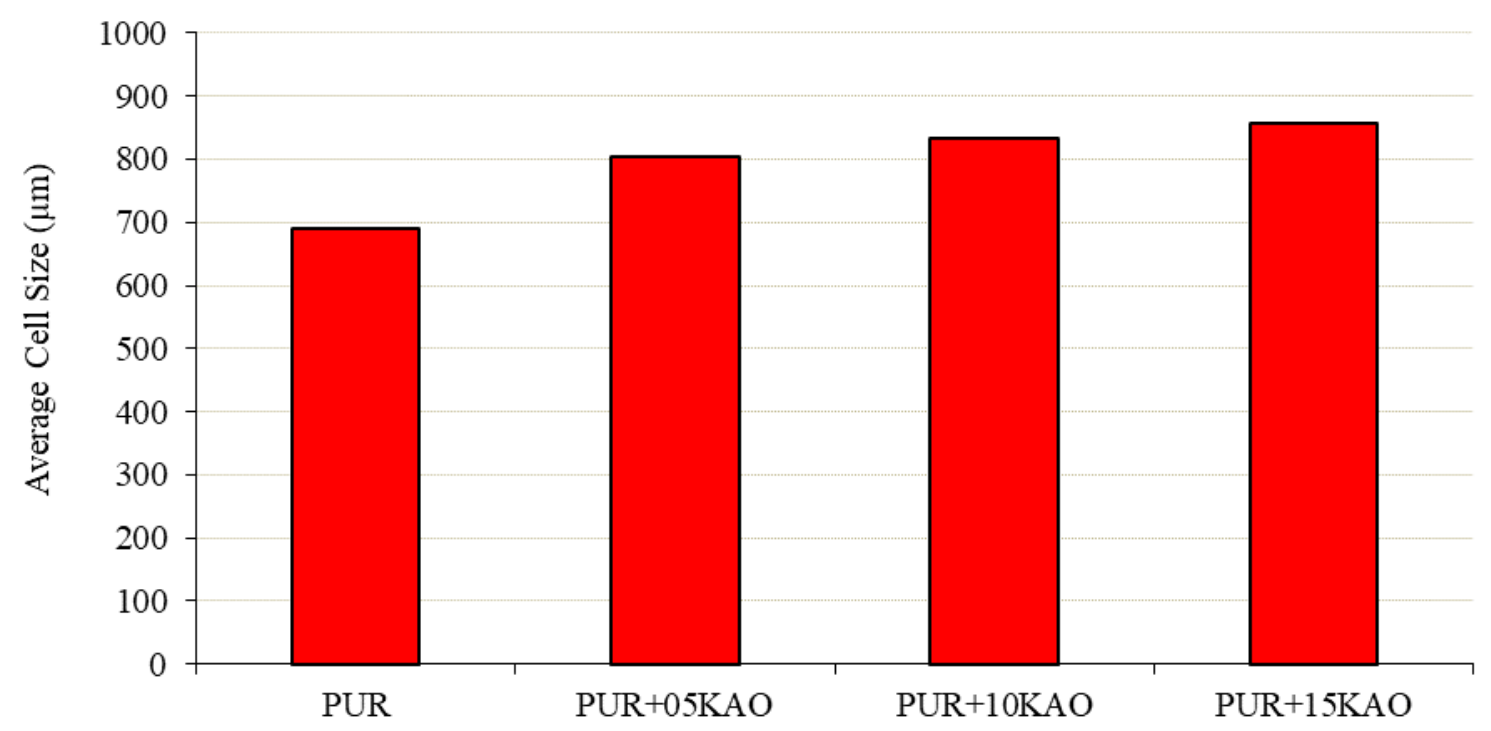

Figure 3. Average cell sizes of PUR and PUR/KAO composites

Figure 4 shows coefficients of thermal conductivity of PUR and PUR/KAO foams in first and fifty fifth days of the foam productions. Although $5 \mathrm{wt}$. \% KAO addition into the rigid polyurethane foam did not significantly affect the thermal conductivity coefficient, 10 and $15 \mathrm{wt}$. \% KAO additions increased it approximately 1.8 and $12.5 \%$ for the first day. The increasing amounts of the coefficients were determined as $1,8.2$ and $10.6 \%$ for $55^{\text {th }}$ day. Thermal conductivity coefficient of rigid polyurethane foam mainly depends on cell size, closed cells content and the gas inside the cells [9, 22, 25]. Increases in the thermal conductivity coefficients of PUR/KAO composites may be explained with increasing cell sizes and decreasing the closed cell content of the foams due to breaking down of cell walls with kaolin particles.

\section{CONCLUDING REMARKS}

Effects of 5, 10 and 15 wt. \% kaolin additions on thermal decomposition, average cell size and thermal conductivity of rigid polyurethane foams were investigated. It was determined that although the incorporation of 

2019

kaolin into the foam resulted in the enhancement of the thermal stability of the foams, it slightly increased the coefficient of thermal conductivity and the average cell size of the foam. As a result, it can be concluded that the kaolin can be used as a cheap filler up to $15 \mathrm{wt}$. \% to decrease the production costs of rigid polyurethane foams without remarkable negative impacts in the thermal insulation of the foams.

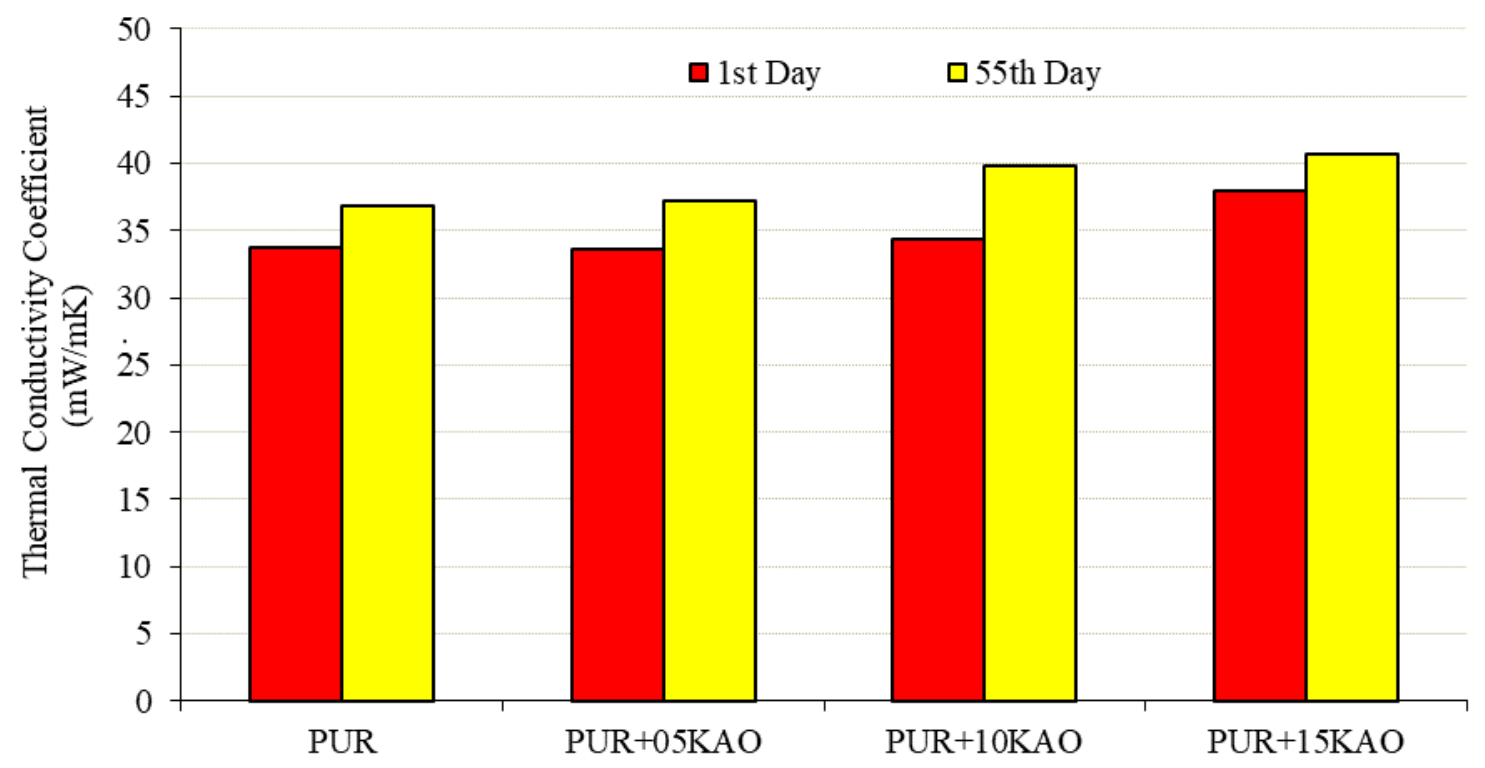

Figure 4. Thermal conductivity coefficients of PUR and PUR/KAO composites

\section{ACKNOWLEDGMENTS}

The authors would like to thank the Pamukkale University Scientific Research Council (BAP) for supporting this study under project contract No. 2014FBE026. Since the some of the equipment and materials were provided with the support of The Scientific and Technological Research Council of Turkey (TUBITAK) under project contract No. 108T246, the authors would like to thank TUBITAK.

\section{NOMENCLATURE}

$\begin{array}{ll}\text { DTG } & \text { Mass loss rate }(\% / \mathrm{min}) \\ \text { KAO } & \text { Kaolin } \\ \text { PUR } & \text { Rigid polyurethane foam } \\ \text { PUR+05KAO } & 95 \% \text { PUR and } 5 \% \text { KAO } \\ \text { PUR+10KAO } & 90 \% \text { PUR and } 10 \% \text { KAO } \\ \text { PUR+15KAO } & \% \text { PUR and } 15 \% \text { KAO } \\ \text { TG } & \text { Mass loss }(\%) \\ \mathrm{T}_{\% 5(\mathrm{~m} / \mathrm{m})}\left({ }^{\circ} \mathrm{C}\right) & \text { Temperature at } 5 \% \text { mass loss } \\ \mathrm{T}_{\% 10(\mathrm{~m} / \mathrm{m})}\left({ }^{\circ} \mathrm{C}\right) & \text { Temperature at } 10 \% \text { mass loss } \\ \mathrm{T}_{\% 50(\mathrm{~m} / \mathrm{m})}\left({ }^{\circ} \mathrm{C}\right) & \text { Temperature at } 15 \% \text { mass loss } \\ \mathrm{T}_{1 \text { maks }}\left({ }^{\circ} \mathrm{C}\right) & \text { Maximum decomposition temperature in } 1^{\text {st }} \text { stage } \\ \mathrm{T}_{2 \text { maks }}\left({ }^{\circ} \mathrm{C}\right) & \text { Maximum decomposition temperature in } 2^{\text {nd }} \text { stage } \\ \mathrm{T}_{3 \text { maks }}\left({ }^{\circ} \mathrm{C}\right) & \text { Maximum decomposition temperature in } 3^{\text {rd }} \text { stage } \\ \mathrm{R}_{1 \text { maks }}(\% / \mathrm{min}) & \text { Maximum decomposition rate in } 1^{\text {st }} \text { stage } \\ \mathrm{R}_{2 \text { maks }}(\% / \mathrm{min}) & \text { Maximum decomposition rate in } 2^{\text {nd }} \text { stage } \\ \mathrm{R}_{3 \text { mak }}(\% / \mathrm{min}) & \text { Maximum decomposition rate in } 3^{\text {rd }} \text { stage } \\ \text { wt. } & \text { Weight }\end{array}$

\section{REFERENCES}

[1] Zheng, X. R., Wang, G. J., Xu, W. (2014). Roles of organically-modified montmorillonite and phosphorous flame retardant during the combustion of rigid polyurethane foam. Polymer Degradation and Stability, 101, 32-39. 
[2] Basso, M. C., Giovando, S., Pizzi, A., Pasch, H., Pretorius, N., Delmotte, L., Celzard, A. (2014). Flexible- Elastic Copolymerized Polyurethane- Tannin Foams. Journal of Applied Polymer Science, 131(13), 40499.

[3] Silva, M. C., Takahashi, J. A., Chaussy, D., Belgacem, M. N., Silva, G. G. (2010). Composites of Rigid Polyurethane Foam and Cellulose Fiber Residue. Journal of Applied Polymer Science, 117(6), 3665-3672.

[4] Anand, Y., Anand, S., Gupta, A., Tyagi, S. K., (2015). Building envelope performance with different insulating materials-An exergy approach. Journal of Thermal Engineering, 1 (4), 433-439.

[5] Modesti, M., Lorenzetti, A., Besco, S. (2007). Influence of nanofillers on thermal insulating properties of polyurethane nanocomposites foams. Polymer Engineering and Science, 47(9), 1351-1358.

[6] Qu, M. H., Wang, Y. Z., Liu, Y., Ge, X. G., Wang, D. Y., Wang, C. (2006). Flammability and thermal degradation behaviors of phosphorus-containing copolyester/BaSO4 nanocomposites. Journal of Applied Polymer Science, 102(1), 564-570.

[7] Ghazinezami, A., Khan, W. S., Jabbarnia, A., Asmatulu, R., (2017). Impacts of nanoscale inclusions on fire retardancy, thermal stability, and mechanical properties of polymeric PVC nanocomposites. Journal of Thermal Engineering, 3(4), 1308-1318.

[8] Czuprynski, B., Paciorek-Sadowska, J., Liszkowska, J. (2010). Properties of Rigid PolyurethanePolyisocyanurate Foams Modified with the Selected Fillers. Journal of Applied Polymer Science, 115(4), 2460-2469.

[9] Fan, H. Y., Tekeei, A., Suppes, G. J., Hsieh, F. H. (2012). Properties of Biobased Rigid Polyurethane Foams Reinforced with Fillers: Microspheres and Nanoclay. International Journal of Polymer Science, $474803(1-8)$.

[10] Kumar, S., Maiti, P. (2015). Understanding the controlled biodegradation of polymers using nanoclays. Polymer, 76, 25-33.

[11] Usta N. (2012) Investigation of fire behavior of rigid polyurethane foams containing fly ash and intumescent flame retardant by using a cone calorimeter. Journal of Applied Polymer Science, 124(4), 3372-3382.

[12] Sari, M. G., Ramezanzadeh, B., Shahbazi, M., Pakdel, A. S. (2015). Influence of nanoclay particles modification by polyester-amide hyperbranched polymer on the corrosion protective performance of the epoxy nanocomposite. Corrosion Science, 92, 162-172.

[13] Pielichowski, K., Kulesza, K., Pearce, E. M. (2002). Flammability of rigid polyurethane foams blown with pentane: Limiting oxygen index data and thermovision characteristics. Journal of Polymer Engineering, 22(3), 195-207.

[14] Li, J., Stoliarov, S. I. (2013). Measurement of kinetics and thermodynamics of the thermal degradation for non-charring polymers. Combustion and Flame, 160(7), 1287-1297.

[15] Ali, V., Neelkamal, Haque, F. Z., Zulfequar, M., Husain, M. (2007). Preparation and characterization of polyether-based polyurethane dolomite composite. Journal of Applied Polymer Science, 103(4), 2337-2342.

[16] Saha, M. C., Kabir, M. E., Jeelani, S. (2008). Enhancement in thermal and mechanical properties of polyurethane foam infused with nanoparticles. Materials Science and Engineering a-Structural Materials Properties Microstructure and Processing, 479(1-2), 213-222.

[17] Aydogan, B., Usta, N. (2015). Experimental investigations of thermal conductivity, thermal degradation and fire resistance of rigid polyurethane foams filled with nano calcite and intumescent flame retardant. Isi Bilimi ve Teknigi Dergisi-Journal of Thermal Science and Technology, 35(2), 6374.

[18] Khan, W. S., Ceylan, M., Jabarrania, A., Saeednia L., Asmatulu, R. (2017). Chemical and thermal investigations of electrospun polyacrylonitrile nanofibers incorparated with various nanoscale inclusions. Journal of Thermal Engineering, 3(4), 1375-1390.

[19] ASTM C1113. (2013). Standard Test Method for Thermal Conductivity of Refractories by Hot Wire, ASTM International, West Conshohocken, PA, U.S.A., 2013.

[20] ASTM D 3576-04. (2004). Standard Test Method for Cell Size of Rigid Cellular Plastics, American Society for Testing and Materials, New York.

[21] Huang, N. N., Wang, J. Q. (2009). A TGA-FTIR study on the effect of CaCO3 on the thermal degradation of EBA copolymer. Journal of Analytical and Applied Pyrolysis, 84(2), 124-130. 
[22] Thirumal, M., Khastgir, D., Singha, N. K., Manjunath, B. S., Naik, Y. P. (2009). Effect of a Nanoclay on the Mechanical, Thermal and Flame Retardant Properties of Rigid Polyurethane Foam. Journal of Macromolecular Science Part a-Pure and Applied Chemistry, 46(7), 704-712.

[23] Zhao, G., Wang, T. M., Wang, Q. H. (2012). Studies on wettability, mechanical and tribological properties of the polyurethane composites filled with talc. Applied Surface Science, 258(8), 3557-3564. [24] Kim, S. H., Lee, M. C., Kim, H. D., Park, H. C., Jeong, H. M., Yoon, K. S., Kim, B. K. (2010). Nanoclay Reinforced Rigid Polyurethane Foams. Journal of Applied Polymer Science, 117(4), 19921997.

[25] Marrucho, I. M., Santos, F., Oliveira, N. S., Dohrn, R. (2005). Aging of rigid polyurethane foams: Thermal conductivity of $\mathrm{N}-2$ and cyclopentane gas mixtures. Journal of Cellular Plastics, 41(3), 207224. 